\title{
Effect of Zinc Supplementation on Thyroid and Testosterone Hormone Levels in Wistar Rats
}

\author{
Juneet Kour, J. Devi", K. Sarma and D. Chakraborty \\ Division of Veterinary Physiology \& Biochemistry, F.V.Sc. and A.H., SKUAST-J, R.S. Pura, \\ Jammu-181102, J\&K, India \\ *Corresponding author
}

\section{Keywords}

Age, Testosterone, Thyroid hormones, Wistar rats, Zinc supplementation

Article Info

Accepted:

15 September 2020 Available Online: 10 October 2020

\section{A B S T R A C T}

The study was conducted on weaned wistar male rats for the period of 8 weeks from 4 to 12 weeks of age and they were divided into 3 groups as control: rats fed diet without zinc supplementation, Treatment groups, T1 and T2: rats fed diet containing zinc sulphate @ $50 \mathrm{mg}$ and $100 \mathrm{mg} / \mathrm{kg}$ body weight/day, respectively. Blood samples were collected from each rat of all the 3 groups on $6,8,10$ and 12 weeks of experiment and plasma were separated and triiodothyronine $\left(\mathrm{T}_{3}\right)$, thyroxine $\left(\mathrm{T}_{4}\right)$ and testosterone levels were estimated. The plasma concentrations of $\mathrm{T}_{3}$ and $\mathrm{T}_{4}$ in wistar rats increased as age advanced from 6 to 12 weeks in all three groups. The $\mathrm{T}_{3}$ values were varied significantly $(\mathrm{P}<0.01)$ with each other in different ages; whereas, $\mathrm{T}_{4}$ levels were recorded significantly higher $(\mathrm{P}<0.01)$ at 10 and 12 weeks as compared to 6 and 8 weeks in all groups. Thyroid hormone concentrations were higher in treatment groups (T1 and T2) as compared to control from 8 weeks of age. As compared to control value, in $\mathrm{T} 1$ group, $\mathrm{T}_{3}$ concentration was significantly higher $(\mathrm{P}<0.01)$ at 8 weeks of age and significantly higher $(\mathrm{P}<0.01) \mathrm{T}_{4}$ values were recorded from 10 weeks; whereas, in $\mathrm{T} 2$ group, $\mathrm{T}_{4}$ levels were significantly higher $(\mathrm{P}<0.01)$ at 10 weeks of age. In between $\mathrm{T} 1$ and $\mathrm{T} 2$ groups, $\mathrm{T}_{3}$ concentrations were found higher at 8 and 10 weeks and $\mathrm{T}_{4}$ values were higher from 8 to 12 weeks of age in $\mathrm{T} 1$ group, but the values were not varied significantly. The plasma concentration of testosterone in all groups showed an increasing trend with the advancing age and the values were varied significantly $(\mathrm{P}<0.01)$ within the group at different ages. When compared between the treatment groups and control, significantly higher $(\mathrm{P}<0.01)$ values were found in both the treatment groups (T1 and T2) as compared to the values of control group from 8 to 12 weeks of age. The present study revealed earlier rise of testosterone in T1 group as compared to T2 group; however, the values were not varied significantly at different ages studied. The study showed that oral zinc supplementation induces a better testosterone and thyroid hormone profile. The concentrations of the hormones in plasma showed an increasing trend with the advancing age.

\section{Introduction}

Zinc plays vital role in anatomical development and normal function of male reproductive organs. Deficiency of this element in diet has been reported to cause delayed testicular development, reduced testosterone production and abolition of 
spermatogenesis (Underwood and Somers, 1977). Pituitary gonadotropin and androgen production have also been reported to be reduced with the deficiency of this element (Martin and White, 1992). A cascade of reactions related to hormone synthesis and secretion essentially involve more minerals than a single as cofactors. Thyroid hormones affect animals' growth and reproduction through their effect on metabolic rate in almost all tissues and stimulate growth in all ages. In animal studies, single and multiple deficiencies of iodine, selenium and zinc have distinct effects on thyroid metabolism and structure. Critical role of zinc in promoting the conversion of thyroid hormones, thyroxin to triiodothyronine has been reported (Nishiyama et al., 1994). Zinc is not widely stored in the body, so its supply in the diet should be continuous. Area specific deficiency of minerals is prevalent in soils in many parts of India and through soil-plant system; it causes mineral deficiency in animals (Khan et al., 1979). In Assam, low soil $\mathrm{pH}$ and high rainfall are attributed to leaching of top soil that could result in mineral deficiency in animals through ingestion of plants grown in such soils. Further, higher iron content of the soil in Assam could be another factor to lower zinc absorption in the animal's gut due to mineral interaction. The use of organic minerals in livestock nutrition has gained considerable interest over the past decade. Zinc supplementation inorganic form in ruminant diets might produce superior results over inorganic form of supplementation because of different pattern of its metabolism (Rojas et al., 1996; Devi et al., 2013) and greater bioavailability than inorganic sources of minerals. It could be anticipated that the zinc supplementation would optimize the growth rate of young male genital system including testosterone secretion from Leydig cells. Keeping in view of the above, the present investigation was taken up to study the effect of zinc supplementation on hormonal concentration in serum in inorganic and organic zinc- supplemented groups of Assam local kids.

\section{Materials and Methods}

The study was conducted in 72 weaned Wistar male rats for a period of 8 weeks from 4 to 12 weeks of age. The experimental rats were divided in to three groups as control: rats fed diet without zinc supplementation, T1 (treatment 1): rats fed diet containing zinc sulphate @ $50 \mathrm{mg} / \mathrm{kg}$ body weight/day and T2 (treatment 2): rats fed diet containing zinc sulphate @ 100 mg/kg body weight/day. The rats were procured from Indian Institute of Integrative Medicine, CSIR Laboratory, Jammu. They were provided standard pelleted ration and clean drinking water ad libitum and maintained under standard managemental conditions. Prior to start of experiment, the rats were acclimatized in the laboratory conditions for a period of one week.

Blood was collected in aliquots containing anticoagulant heparin @ $10 \mathrm{IU} / \mathrm{ml}$ of blood and the samples were centrifuged at $3000 \mathrm{rpm}$ for 15 minutes. Plasma was harvested in clean sterile glass test tubes and was immediately stored at $-20^{\circ} \mathrm{C}$ for biochemical analysis. Plasma hormones viz. triiodothyronine $\left(\mathrm{T}_{3}\right)$, thyroxine $\left(\mathrm{T}_{4}\right)$ and testosterone concentrations were estimated by Enhanced Chemiluminescence method. For all the observed data in the present experiment, the standard statistical procedures recommended by Snedecor and Cochran (2004) have been followed. The data were presented by showing mean and standard error. The significant differences of values for different parameters studied were assessed by the test of one way and two-way analysis of variance depending upon the data. The significant values of different groups and weeks were calculated by Tukey's test. All the above 
calculations were carried out using SPSS software version 16.0.

\section{Results and Discussion}

Thyroid hormones (Triiodothyronine, $\mathbf{T}_{3}$ and Thyroxine, $\mathbf{T}_{4}$ )

In the present study (Table 1), it was observed that both thyroid hormone $\left(\mathrm{T}_{3}\right.$ and $\left.\mathrm{T}_{4}\right)$ levels were higher in treatment groups (T1 and $\mathrm{T} 2)$ as compared to the control from 8 weeks of age. As compared to control, the value in $\mathrm{T} 1$ group, $\mathrm{T}_{3}$ concentration was significantly higher $(\mathrm{P}<0.01)$ at 8 weeks of age and significantly higher $(\mathrm{P}<0.01) \mathrm{T}_{4}$ values were recorded from 10 weeks; whereas, in $\mathrm{T} 2$ group, $\mathrm{T}_{4}$ levels were significantly higher $(\mathrm{P}<0.01)$ at 10 weeks of age. Increased plasma concentrations of thyroid hormones in zinc-supplemented groups might be related to stimulatory effect of zinc on thyroid hormone biosynthesis for augmentation of body metabolism. According to Baltaci et al., (2004) zinc had an important role in thyroid metabolism and it participated in the formation and action of thyrotropin-releasing hormone (Pekary et al., 1991). Other reports in the literature which supported the present findings regarding the secretion of thyroid hormones following zinc supplementation in rats and other species (Smit et al., 1993; Nishiyana et al., 1994; Taneja et al., 2006; Kumar et al., 2013). Studies being carried out on rats also revealed that the hypothalamic thyrotropic hormone content decreased in zinc deficiency (Morley et al., 1980). In support to the present finding, earlier reports suggested that zinc deficiency caused atrophy of the thyroid gland with degeneration of the thyroid follicles (Gupta et al., 1988; Gupta et al., 1997). The $T_{3}$ receptor is thought to require zinc to adopt its biologically active conformation and some of the effects of zinc deficiency, therefore, might be due to loss of zinc from the $T_{3}$ receptor and impairment of
$\mathrm{T}_{3}$ action (Freake et al., 2001). Between $\mathrm{T} 1$ and $\mathrm{T} 2$ groups, $\mathrm{T}_{3}$ concentrations were found higher at 8 and 10 weeks and $\mathrm{T}_{4}$ values were higher from 8 to 12 weeks of age in T1 group, but there was no significant variation observed between the values of treatment groups. The plasma concentrations of triiodothyronine $\left(\mathrm{T}_{3}\right)$ and thyroxine $\left(\mathrm{T}_{4}\right)$ in Wistar rats increased as age advanced from 6 to 12 weeks. The $\mathrm{T}_{3}$ values were varied significantly $(\mathrm{P}<0.01)$ with each other at different ages in all the three groups; whereas, $\mathrm{T}_{4}$ levels were recorded significantly higher $(\mathrm{P}<0.01)$ at 10 and 12 weeks as compared to 6 and 8 weeks in all the groups. The concentration of $\mathrm{T}_{3}(\mathrm{ng} / \mathrm{dl})$ ranged between $80.17 \pm 2.23$ to $158.65 \pm 3.29 ; 87.15 \pm 2.05$ to $170.02 \pm 2.88$ and $88.80 \pm 1.63$ to $170.32 \pm$ 2.02 from 6 to 12 weeks in control, T1 and T2 groups, respectively. No reasons for such an age-different responses could be assigned, however, increase in size and activity of the thyroid gland as advancement of age might be the reason for increased level of thyroid hormones at active growth period of 6 to 12 weeks in Wistar rats.

\section{Plasma testosterone}

When compared between the treatment groups and control (Table 1), significantly higher $(\mathrm{P}<0.01)$ testosterone concentrations were found in both the treatment groups (T1 and T2) as compared to the values of control group from 8 to 12 weeks of age. Dissanayake et al., (2004) observed zinc treatment for two weeks caused a significant increase $(\mathrm{P}<0.05)$ in serum testosterone level in rats. In male albino Wistar rats, Egwuruguru et al., (2013) also found significant increase in serum levels of testosterone with different doses of $20 \mathrm{gm} / 2.5 \mathrm{~kg}$ diet, $40 \mathrm{gm} / 2.5 \mathrm{~kg}$ diet and $80 \mathrm{gm} / 2.5 \mathrm{~kg}$ diet of zinc supplementation when compared to control group and recorded the mean values of testosterone to be $360 \pm$ $1.4 \mathrm{ng} / \mathrm{dl}, 450 \pm 0.30 \mathrm{ng} / \mathrm{dl}$ and $80 \pm 0.70$ 
ng/dl, respectively. The results agree with the work of Abdella et al., (2011), Omu et al., (2015) and Ratnasooriya et al., (2004) in rats. Zinc supplementation activates the secretion and action of testosterone and can lead to increased efficiency of spermatogenic machinery and increased number of germ cells in the seminiferous tubules (Pizent $e t$ al., 2003; Abdella et al., 2011) which was also reflected in the present study (Plate 13). Zinc ion modulates the secretion of testosterone in Leydig cells (Mehta et al., 1989).

Table.1 Plasma hormone concentrations in male wistar rats following zinc supplementation

\begin{tabular}{|c|c|c|c|c|}
\hline \multirow[t]{2}{*}{ Group } & \multicolumn{4}{|c|}{ Age in weeks } \\
\hline & 6 & 8 & 10 & 12 \\
\hline \multicolumn{5}{|c|}{ Triiodothyronine $\left(T_{3}\right)$ concentration $(\mathrm{ng} / \mathrm{dl}$, Mean \pm S.E) } \\
\hline Control & $80.17^{\mathrm{a}} \pm 2.23$ & $96.85^{\mathrm{bA}} \pm 3.34$ & $134.73^{\mathrm{c}} \pm 3.80$ & $158.65^{\mathrm{d}} \pm 3.29$ \\
\hline Treatment (T1) & $87.15^{\mathrm{a}} \pm 2.05$ & $110.10^{\mathrm{bB}} \pm 5.10$ & $146^{\mathrm{c}} \pm 4.56$ & $170.02^{\mathrm{d}} \pm 2.88$ \\
\hline Treatment (T2) & $88.80^{\mathrm{a}} \pm 1.63$ & $105.27^{\mathrm{bAB}} \pm 4.84$ & $145.92^{\mathrm{c}} \pm 3.77$ & $170.32^{\mathrm{d}} \pm 2.02$ \\
\hline \multicolumn{5}{|c|}{ Thyroxine $\left(T_{4}\right)$ concentration $(\mu \mathrm{g} / \mathrm{dl}, \mathrm{Mean} \pm \mathrm{S} . \mathrm{E})$} \\
\hline Control & $4.60^{\mathrm{a}} \pm 0.22$ & $5.23^{\mathrm{a}} \pm 0.18$ & $6.58^{\mathrm{bA}} \pm 0.20$ & $7.47^{\mathrm{bA}} \pm 0.26$ \\
\hline Treatment (T1) & $5.00^{\mathrm{a}} \pm 0.34$ & $5.87^{\mathrm{a}} \pm 0.25$ & $7.72^{\mathrm{bB}} \pm 0.25$ & $8.52^{\mathrm{bB}} \pm 0.35$ \\
\hline Treatment (T2) & $5.22^{\mathrm{a}} \pm 0.21$ & $5.83^{\mathrm{a}} \pm 0.19$ & $7.57^{\mathrm{bB}} \pm 0.32$ & $8.13^{\mathrm{bAB}} \pm 0.30$ \\
\hline \multicolumn{5}{|c|}{ Testosterone concentration (ng/dl, Mean \pm S.E) } \\
\hline Control & $280.75^{\mathrm{a}} \pm 10.40$ & $388.60^{\mathrm{bA}} \pm 20.88$ & $552.83^{\mathrm{cA}} \pm 20.50$ & $657.15^{\mathrm{dA}} \pm 15.60$ \\
\hline Treatment (T1) & $298.80^{\mathrm{a}} \pm 11.45$ & $521.85^{\mathrm{bB}} \pm 11.87$ & $685.92^{\mathrm{cB}} \pm 1.35$ & $759.63^{\mathrm{dB}} \pm 12.92$ \\
\hline Treatment (T2) & $294.30^{\mathrm{a}} \pm 12.69$ & $499.78^{\mathrm{bB}} \pm 8.94$ & $645.83^{\mathrm{cB}} \pm 7.17$ & $734.03^{\mathrm{dB}} \pm 8.39$ \\
\hline
\end{tabular}

$\mathrm{a}, \mathrm{b}$ describes significant differences within groups between age in weeks

A, B describes significant differences within age in weeks between groups

The production of hormone by the pituitary gland was also affected when the diet was deficient in zinc (Hidiroglou and Knipfel, 1984; Reeves and Odeel, 1988). Bedwal and Bahuguna (1994) also reported that zinc is an important mineral required for reproduction in both male and female and it plays an essential role in testicular steroidogenesis, androgen metabolism and interaction with steroid receptors. It plays an important role in the production, storage and secretion of individual hormones including effectiveness of receptor sites in the target cells (McDowell et al., 1993). Earlier literature (Stamatiadis et al., 1988) also suggested that zinc is vital to growth and maturation of human spermatozoa and it has role for the conversion of testosterone into bioactive form alphadehydrotestosterone (DHT). Zinc also inhibits the aromatase enzyme that converts testosterone into excess estrogen. It is required for normal functioning of the hypothalamic-pituitary-gonadotaxis (Miller $e t$ al., 1958; Lei et al., 1976).

The present study revealed earlier rise of testosterone in $\mathrm{T} 1$ group as compared to $\mathrm{T} 2$ group; however, the values did not vary significantly at different ages studied. These finding suggested that zinc @ $50 \mathrm{mg} / \mathrm{kg}$ body weight/day (T1) had beneficial effect over zinc dose @ 100mg/kg body weight/day (T2) on reproductive performances of male animals by increasing the secretion of male hormone testosterone. Koehler et al., (2009) reported that over supplementation of zinc has no effect on testosterone level. 
In the present study (Table 1), it was observed that the plasma concentration of testosterone in all the groups showed an increasing trend with advancing age and the values varied significantly $(\mathrm{P}<0.01)$ within the group at different ages. The levels increased from $280.75 \pm 10.40$ to $657.15 \pm 15.60 \mathrm{ng} / \mathrm{dl}$ in control, $298.80 \pm 11.45$ to $759.63 \pm 12.92$ $\mathrm{ng} / \mathrm{dl}$ in $\mathrm{T} 1$ and $294.30 \pm 12.69$ to $734.03 \pm$ $8.39 \mathrm{ng} / \mathrm{dl}$ in T2 groups. Sexual development was investigated (Zanato et al., 1994) in male Wistar rats from 22 to 97 days of age and the first significant increase of plasma testosterone was observed from 40 to 50 days of age and a progressive enhancement was observed thereafter to a maximum at 76 days. Swain and Singh (2004) estimated blood testosterone levels in Sahiwal bulls and found that the level of testosterone was positively correlated with the age of the animals.

\section{References}

Abdella, A. M., Elabed, B. H., Bakhiet, A. O., Gadir, W. S. A. and. Adam, S. E. I. 2011. In vivo, Study on Lead, Cadmium and Zinc Supplementations on Spermatogenesis in Albino Rats. Journal of Pharmacology and Toxicology, 6(2): 141-148.

Baltaci, A. K., Mogulkoc, R., Kul, A., Bediz, C. S. and Ugur, A. 2004.Opposite effects of zinc and melatonin on thyroid hormones in rats. Toxicology, 195(1): 69-75

Bedwal, R. S. and Bahuguna, A. 1994.Zinc, copper and selenium in reproduction. Experientia, 50(7): 626-640.

Devi, J., Goswami, J., Sarma, B.C. and Sarma, K.2013. Effect of zinc supplement on histology of epididymis in Assam local goat (Capra hircus). Ruminant Science 2(2):171-173.

Dissanayake, D. M. A. B., Wijesinghe, P. S., Ratnasooriya, W. D. and Wimalasena, S. 2004. Effects of Zinc supplementation on sexual behavior of male rats. Journal of Human Reproductive Sciences, 2(2): 57-61.

Egwurugwu, J. N., Ifedi, C. U., Uchefuna, R. C., Ezeokafor, E. N. and Alagwu, E. A. 2013. Effects of zinc on male sex hormones and semen quality in rats. Nigerian Journal of Physiological Sciences, 28: 017-022.

Freake, H. C., Govoni, K. E., Guda, K., Huang, C. and Zinn, S. A. 2001. Actions and interactions of thyroid hormone and zinc status in growing rats. Journal of Nutrition, 131(4): 1135-1141.

Gupta R. P., Verma P. C., Sadana J. R. and Paul Gupta, R.K. 1988.Studies on the pathology of experimental zinc deficiency in guinea-pigs. Journal of Comparative Pathology, 98: 405-413.

Gupta, R.P., Verma, P.C. and Garg, S.L. 1997. Effcet of experimental zinc deficiency on thyroid gland in guineapigs. Annals of Nutrition and Metabolism, 41(6): 376-381.

Hidiroglou, M. and Knipfel, J.E. 1984. Zinc in mammalian sperm: A review. Journal of Dairy Science, 35(1): 11751185.

Khan, S.A., Bedi, S.P.S., Sawhney, P.C. and Ranjan, S.K. 1979. Zinc status of soil, plant and animals in Tarai area (U.P.). Indian Journal of Animal Science, 49:612-17.

Koehler, K., Parr, M. K., Geyer, H., Mester, J. and Schanzer, W.2009. Serum testosterone and urinary excretion of steroid hormone metabolites after administration of a high-dose zinc supplement. European Journal of Clinical Nutrition. 63(1): 65-70.

Kumar, P., Yadav, B. and Yadav, S. 2013. Effect of zinc and selenium supplementation on antioxidative status of seminal plasma and testosterone, T4 and T3 level in goat 
blood serum. Journal of Applied Animal Research, 41: 4, 382-386.

Lei, K.Y., Abbasi, A. A. and Prasad, A. A. 1976. Function of pituitary-gonadal axis in zinc deficient rats. American Journal of Physiology,230: 17301732.

Martin, G.B. and White, C.L. 1992. Effect of dietary zinc deficiency on gonadotrophin secretion and testicular growth in young male sheep.Journal of Reproduction and Fertility, 96:497507.

McDowell, L. R., Conrad, J. H. and Hembry, H. 1993. Minerals for grazing ruminants in tropical regions, $2^{\text {nd }}$ Edn., Animal Science Department, University of Florida.

Mehta, U., Mehta, S. N., Georgie, G. C., Mehta, S., Dixit, V. P. and Verma, P. C. 1989. Effect of dietary zinc and copper on peripheral blood plasma cholesterol, testosterone and histomorphology of testes in rats. Indian Journal of Experimental Biology, 27:469-471.

Miller, M.J.; Fisher, M.I; Elocote, P.V. and Mawson, C.A. 1958.The effects of dietary zinc deficiency on the reproductive system of male rats.Canadian Journal of Biochemistry and. Physiology, 36:557-569.

Morley, J. E., Gordon, J. and Hershman, J. M. 1980. Zinc deficiency chronic starvation and hypothalamic-pituitarythyroid function. The American Journal of Clinical Nutrition,33(8): 1767-1770.

Nishiyama, S., Futagoishi-Suginohara, Y., Matsukura, M., Nakamura, T., Higashi, A., Shinohara, M. and Matsuda, I. 1994. Zinc supplementation alters thyroid hormone metabolism in disabled patients with zinc deficiency. Journal of the American College of Nutrition,
13:62-67.

Nishiyana, S., Futagoishi-Suginohara, Y., Matsukura, M., Nakamura, T., Higashi, A., Shinohara, M. and Matsuda, I. 1994. Zinc supplementation alter thyroid hormone metabolism in disabled patient with Zinc deficiency. Journal of the American College of Nutrition Impact, 13(1): 62-67.

Omu, A.E., Al-Azemi, M. K., Al-Maghrebi, M., Mathew, C. T., Omu, F.E., Kehinde, E. O., Anim, J. T., Oriowo, M. A. and Memon, A. 2015. Molecular basis for the effects of zinc deficiency on spermatogenesis: An experimental study in the Spraguedawley rat model. Indian Journal of Urology, 31: 57-64.

Pekary, A. E., Lukaski, H. C., Mena, I. and Hershman, J. M. 1991. Processing of TRH precursor peptides in rat brain and pituitary is zinc dependent. Peptides, 12(5): 1025-1032.

Pizent, A., Jurasovi, J. and Telisman, S. 2003. Serum calcium, zinc and copper in relation to biomarkers of lead and cadmium in men. Journal of Trace Elements in Medicine and Biology, 17: 199-205.

Ratnasooriya, W. D., Jayakody, J. R. and Dharmasiri, M. G. 2004. Effects of Terminaliacatappa seeds on sexual behavior and fertility of male rats. Asian Journal of Andrology, 2(3): 21319.

Reeves, P. G. and Odeel, B. L. 1988. Zinc deficiency in rats and angiotensin converting enzyme activity: comparative effects on lung and testes. Journal of Nutrition, 118(1): 622-626.

Rojas, L.X., McDowell, L.R., Martin, F.G., Wilkinson, N.S., Johnson, A.B. and Njeru, C.A. 1996. Relative bioavailability of zinc methionine and two inorganic zinc sources fed to 
cattle. Journal of Trace Elements in Medicine and Biology, 10:205-209.

Smit, J. G., Van der Heide, D., Van Tintelen, G. and Beynen, A. C. 1993. Thyroid function in rats with iodine deficiency is not further impaired by concurrent marginal zinc deficiency. British Journal of Nutrition, 72(2): 585-592.

Snedecor, G. W. and Cochran, W. G. 2004. Statistical Methods, $8^{\text {th }}$ Edn., Oxford and IBH Pub. Co., Kolkata.

Stamatiadis, D., Marie-Claire, B-P.and Irene, M. 1988. Inhibition of $5 \alpha$-reductase activity in human skin by zinc and azelaic acid. British Journal of Dermatology, 119(5): 627-632.

Swain, A.K. and Singh, S.V. 2004. Reaction time, seminal fructolytic index and blood testosterone levels in sahiwal bulls. Indian Veterinary Journal, 81 (4): 452-453.

Taneja, S. K., Mandal, R. and Girhotra, S. 2006. Long term excessive zinc supplementation promotes metabolic syndrome- $\mathrm{X}$ in Wistar rats fed sucrose and fat rich semi-synthetic diet. Indian Journal of Experimental Biology, 44: 705-715.

Underwood, E.J. and Somers, M. 1977. Zinc: Trace elements in human and animal nutrition. New York, Academic Press, 196-242.

Zanato, V. F., Martins, M. P., AnselmoFranci, J. A., Petenusci, S. O. and Lamano-Carvalho, T. L. 1994. Sexual development of male Wistar rats. Brazilian Journal of Medical and Biological Research, 27(5): 1273-80.

\section{How to cite this article:}

Juneet Kour, J. Devi, K. Sarma and Chakraborty, D. 2020. Effect of Zinc Supplementation on Thyroid and Testosterone Hormone Levels in Wistar Rats. Int.J.Curr.Microbiol.App.Sci. 9(10): 1829-1835. doi: https://doi.org/10.20546/ijcmas.2020.910.223 